Western University Scholarship@Western

1974

\title{
Canada's Future in a World of Trade Blocs: A Proposal
}

Ronald J. Wonnacott

Follow this and additional works at: https://ir.lib.uwo.ca/economicsresrpt Part of the Economics Commons

Citation of this paper:

Wonnacott, Ronald J.. "Canada's Future in a World of Trade Blocs: A Proposal." Department of Economics Research Reports, 7408. London, ON: Department of Economics, University of Western Ontario (1974). 
Research Report 7408

CANADA'S FUTURE IN A WORLD OF

TRADE BLOCS : A PROPOSAL

R. J. Wonnacott

June 1974

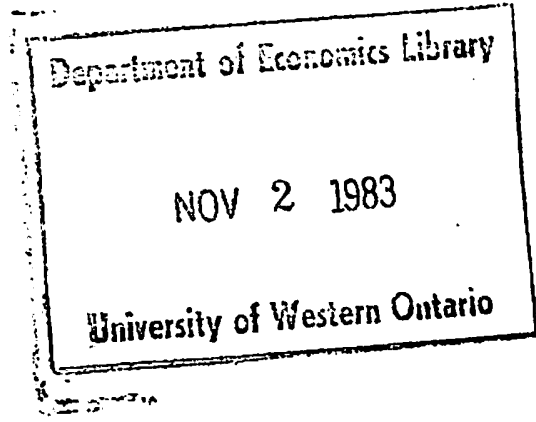




\section{The Problem}

As the world increasingly subdivides into trade blocs, expressions of concern are heard from many quarters. Nowhere, however, should the concern be so strongly felt as in Canada--since we are about the only remaining industrially developed country without free access to one of the large markets on which industrial efficiency is now predicated. 1

\section{It is important to recognize how the formation of trade blocs affects} various countries in quite different ways; it makes a lot of difference whether a country is joining a bloc (like the U.K.), or has always been in one (like the U.S.), or remains an excluded outsider (like Canada). Specifically, consider the creation and expansion of the European trading bloc from these three points of view. First, the participating Europeans do not view this development with alarm, often pointing out that they are simply "catching up" to the Americans by forming the sort of large market that U.S. producers have always enjoyed. On the other hand, Americans voice concern over the damage this will do to U.S. interests, $^{3}$ a point that is well taken, but must be kept in perspective: U.S. producers have always enjoyed a market of equivalent size. Finally, the concern

${ }^{1}$ Economies of market size include both economies of scale in production and other increased efficiencies induced by a larger market (including reduced unit selling costs and the greater discipline a more competitive market provides over various oligopoly excesses). There is now available plentiful documentation of how our inability to achieve economies of scale in our relatively small market has raised Canadian costs. Although these economies are relatively modest on the margin, they become substantial when applied over the very large increase in output in many activities and processes that would be made possible by free access to the large markets that our foreign competitors enjoy. For a listing of 10 research studies that have confirmed and measured economies of scale in Canada, see [ 7], Ch. 2 .

2 The focus in this paper is on trade in industrial goods; in that frame of reference, the European free trade bloc now includes both old and new members of the EEC and those countries like Sweden with special industrial free trade agreements with the EEC.

3 Initially, overriding political objectives ("the unification of Europe") muted any U.S. economic concerns; thus in the early years, the Americans did not press their case for GATT compensation. But recently the U.S. has become more concerned with economic implications and has recently been negotiating strongly (and successfully) for compensation for damage incurred from the expansion of European markets. 
voiced by Canadians is of a much more fundamental kind. As outsiders (like the Americans) we now face costs because discrimination against our goods has been created in European markets. ${ }^{1}$ But unlike the Americans, we have no large market of our own in which to operate. We are not in one of these large markets, complaining about exclusion from the other; instead we are in none, suffering from exclusion from both. Discrimination against us in Europe is now being added to the (more costly) discrimination against us that has existed ever since the U.S. tariff was first established, encircling over $9 / 10$ of the North American market. ${ }^{2}$ The Canadian response to this problem is to favour a multilateral approach to trade liberalization. But so, by and large, do all the other industrial countries now ensconced in their respective blocs; so this is not the issue. Rather, the question is: "Given the economic costs, why are we so resigned to remaining an outsider?"

It is true that the eventual complete success of the multilateral CATT approach would effectively dissolve all existing trade blocs (and the discrimination against us implied in each). But the problem is that essentially complete removal of industrial tariffs (and substantial assurance that they will not be arbitrarily reimposed) is required to open foreign markets enough to justify the necessary widespread scaling up of Canadian industry; and this is definitely not in the cards for this GATT round, and is very unlikely to result from any further

${ }^{1}$ For example, the Germans now receive preferential access into French markets over Canadians because German goods now enter France duty free.

${ }^{2}$ Had the EEC never been formed, Canada would not now face as severe discrimination in Europe; similarly, had the States never United, Canada would not now face as severe discrimination in North America. (More specifically, suppose North America had always been split into 11 economies, one of which was Canada--each with its own tariff protection. If the 10 "U.S." parts were now to be forming a Customs Union, the discrimination that Canadian producers would face as a consequence would be immediately evident. This is precisely the problem that we have always faced.)

of course, the Canadian tariff discriminates against U.S. producers in the Canadian market. But this hurts U.S. producers in less than $1 / 10$ of the North American market, while the U.S. tariff hurts Canadian producers in over $90 \%$ of the North American market. 
rounds in the near future. So, no matter how desirable this eventual objective may be, we should be asking: "Isn't there some other initiative (consistent with multilateralism) that would help us solve our immediate problem?

\section{The Proposal}

This is the recommendation: Canada should now simultaneously approach the U.S. for an industrial ${ }^{1}$ free trade agreement, and simultaneously (or soon thereafter) approach the EEC for an industrial free trade agreement (along the lines of the present Swedish/EEC trade agreement), and approach the remaining EFTA countries (in particular, Sweden and Switzerland) for a similar agreement with them. This solution is not a simple one, and involves substantial problems; but it may be the best means of satisfying both our economic and political objectives.

\section{The Rationale}

From a purely economic point of view, any Canadian free trade area association requires that the U.S. be one of the partners. A much more detailed analysis of this issue has been undertaken elsewhere ([7], Ch. 6 and Part III); while the argument cannot possibly be formally reproduced in this paper, its main points can be roughly sketched out, as follows. A free trade association with the U.S. would be economically more beneficial than a similar arrangement with any other country or group of countries; in comparison with say Europe (our 'next best' bilateral partner), a U.S. association would both generate more gains from trade, ${ }^{2}$ and

This proposal is restricted to industrial goods only because there will be enough difficulty in negotiating this without introducing the relatively intractable problems of agriculture. Since economies of scale tend to be concentrated in industrial products, this is where our problem of inadequate market size lies; in other words, substantial gains would accrue to Canada from industrial free trade only. But there would be further gains from agricultural liberalization which would be welcome if they could be negotiated.

2 Most of our present trade (i.e., about $70 \%$ ) is with the U.S., while much less (about 15\%) is with Europe. Moreover, since our present trade with both partners is now deterred by rough1y the same (MFN) trade barriers, there is a strong expectation that Canada's free trade pattern would remain concentrated (though probably not to precisely this same degree) with the U.S.; (there are a number of reasons for this, not the least of which is the effect of the Atlantic Ocean in deterring trade). This in turn suggests a greater increase in trade (and gains from trade) in a U.S. rather than European association. 
involve less cost (in the form of distorting trade with excluded countries). ${ }^{1}$

Furthermore an even stronger conclusion is warranted: whereas the economic

benefits of a free trade association with the U.S. would exceed the costs, ${ }^{2}$

no similar claim can be made for such an association with any other partner

(or group of partners). Hence an economic requirement for any free trade

area is that the U.S. be included.

But the problem, of course, with a bilateral association with the U.S.

alone is political. It has been argued elsewhere in [4] and [ 7 ] that Canadian fears of being necessarily absorbed by the U.S. (or even of losing a substantial degree of our present independence) in a free trade area do not stand up well under critical analysis. But since political reality is often what people think the situation is, rather than what it really is, there are clearly political advantages in directing any Canadian approach to a broader group of countries.

${ }^{1}$ An important element of this cost, of course, would be classical trade diversion; and in a Canada-U.S. free trade area, this would occur only in that $30 \%$ of our trade with excluded (i.e., non-U.S.) countries, whereas in a Canada-Europe association, this would occur in that $85 \%$ of our trade with excluded (i.e., non-European) countries. It should be emphasized that trade diversion costs occur even if excluded countries' policies do not change. This is a critical point, because another important--perhaps even more important-cost to Canada could result from possible retaliatory economic policies by countries excluded from an agreement. In this regard, any European reaction to exclusion from a Canada-U.S. free trade area is unlikely to compare with the U.S. reaction to a bilateral Canada-Europe association. This is easily inferred by noting present U.S. anger at the extension of European preferences into relatively unimportant Mediterranean markets; any reasonable extrapolation of this implies a very strong American reaction to an extension of these preferences into canada--their most important market, and one which is in addition right in the heartland of North America. Moreover, this means that the problems involved go beyond just the costs to Canada: the expectation that the resulting U.S. ire would be turned against Europe as well as Canada (thus damaging European interests in the U.S. market) means that the Europeans would not entertain such a bilateral arrangement.

2 In fact, it has been estimated [ 6 ] that free trade with the U.S. would raise Canadian real income by slightly more than $10 \%$; and although some Canadian economists may view this estimate as now being somewhat too high (or, in the long run, as perhaps too low), no Canadian economist has estimated the economic effect substantial) taste of these benefits has recently been experienced in the auto industry, in the form of higher Canadian wages.)

For other estimates of the economic effects of liberalizing trade with the

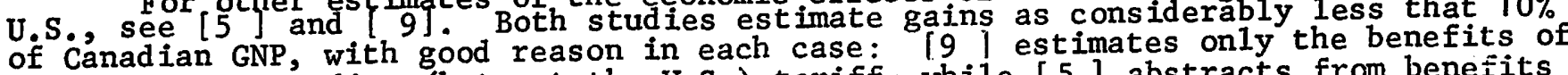
of Canadian GNP, with good reason in each case: based on economies of scale. 
A trilateral Canada-U.S.-Europe free trade association would be an obvious solution to this Canadian dilemma. Moreover, it would be economically more beneficial (as well as politically more acceptable) than a bilateral arrangement with the U.S. alone. In particular, adding Europe to a Canada/U.S. association would involve increased trade creation benefits, but none of the major costs cited above that would complicate a bilateral Canada/Europe free trade agree.ment. $^{2}$ There is only one problem: the Europeans and Americans would not have it. They show no willingness at this juncture to completely eliminate tariffs against each other. ${ }^{3}$ This is the fundamental reason why the GATT multilateral negotiations will not completely succeed in the near fucure in eliminating industri.al tariffs. In other worcis, what prevents free trade on the multilateral front also prevents a full triangular free trade arrangement between Canada, Europe and the U.S.

Which raises the final question: if this triangle is not feasible because one side (U.S./Europe) cannot be negotiated, why not get what we can, and try for the remaining two sides? That is precisely the proposal: industrial free trade simultaneously with the U.S. on one hand, and with Europe on the other, as shown in Figure 1.

${ }^{1}$ Recall that we are discussing free trade in industrial products only. Noting also that the EEC and important remaining EFTA countries are already trading these goods freely (hence are already in one market), we hereafter refer to them both together as simply "Europe". (But our subsequent argument holds, of course, if either the EEC or remaining EFTA countries decided not to participate--in which case Europe would be defined more narrowly.)

${ }^{2}$ For example, because the Europeans would not get preferential access over the Americans into the Canadian market, there would be no reason for a hostile U.S. reaction.

${ }^{3}$ In particular, the Europeans still view some remaining common external tariff against the U.S. as a 'pillar' or 'necessary cement' for the common market. 


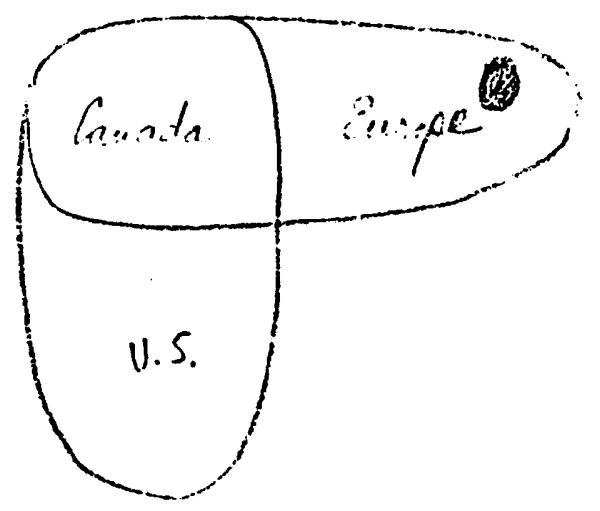

Figure 1. Proposed Overlapping Free Trade Areas

4. The Theory of Overlapping Free Trade Areas.

This proposal raises a number of interesting issues. First, would the origin requirements necessary in any free trade area become hopelessly complex in this more complicated three-way scheme? The answer is no: the Americans would monitor imports from Canada as though only a Canada/U.S. free trade area existed; the Europeans would monitor imports from Canada as though only a Canada/Europe free trade existed; and Canada would monitor imports from both (as though a full triangular arrangement existed ${ }^{1}$ ). In short, there would be no new problems beyond those already successfully dealt with in the monitoring of many existing free trade areas.

Second, such a two-sided triangle would be more beneficial for the 'pivot country' (Canada) than a full triangle including all three sides; the reason is that Canada would enjoy preferred access into the European market vis-à-vis the U.S., and similarly preferred access into the U.S. market vis-a-vis Europe. Because $85 \%$ of Canada's total trade is concentrated in these two markets, we would be getting free access into our two most important markets, at the same time Details would be different, but the monitoring involved would be no more
difficult. ${ }^{1}$ Details would be different, but the monitoring involved would be no more
difficult. 
enjoying preferential treatment in each against the other. 1 Accordingly it would be not only more beneficial for Canada than a full triangle; it is even possible that it might be more beneficial for Canada than full multilateral free trade.

But the same reasons that make the two-sided triangle more attractive for Canada would also make it less attractive for the Americans and Europeans. 2 In fact, when this idea first occurred, this author's first reaction was: "This idea is so unprecedented and asymmetrically beneficial for Canada that it could not possibly be sold." On further reflection, however, the following conclusions emerge: (1) there are many precedents, none of which have involved serious complaints about the asymetric benefits to the pivot country; (2) although major political difficulties would have to be overcome, there is a substantial chance that it could be sold to Europe and the U.S.; (3) the major problem might be to sell it to those who would be the major beneficiaries of its asymmetrical advantages--Canadian producers. Consider each of these points in turn.

\section{Precedents}

As a result of EFTA, the EEC and a number of other trading agreements, the map of Europe is now studded with overlapping free trade (or preferential) arcas, 3 as illustrated in Figures 2 and 3. Figure 2 shows the British enjoying preferential access to two markets at once. Panel (a) shows the situation prior to recent British entry into the EEC; at that time the British enjoyed preferential access into EFTA, as well as into the Commonwealth. 4

'And, of course, against all 'fourth' countries.

2 For example, preferences granted to us over the Europeans in the U.S. market would result in some shift of American purchases from least cost (European) sources to Canada. This would almost certainly represent a benefit for Canada, but a cost for both the U.S. and Europe. (For details, see the discussion of partners' dirnrsion in Ch. 3 of [7].)

${ }^{3}$ Including, of course, customs unions.

${ }^{4}$ Although Commonwealth preference was not of the limiting complete free trade variety, it still provided the U.K. with the asymetrical advantages of a pivot country. 


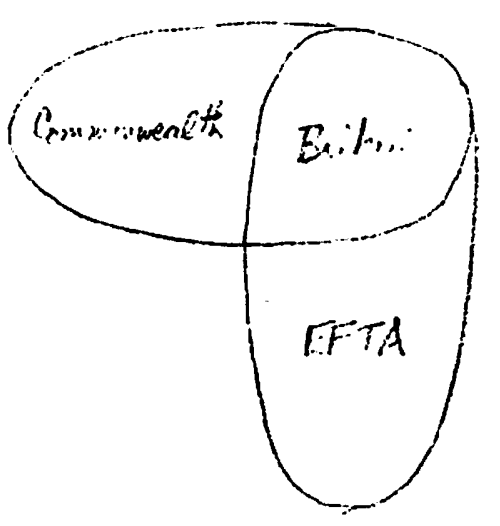

a) Prior to British entry into F.EC

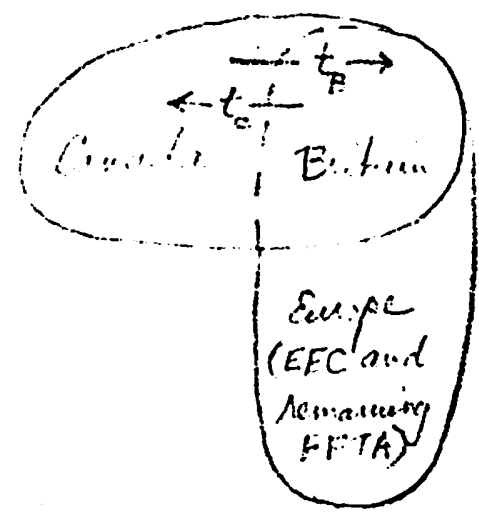

b) Since British entry

Figure 2. The U.K. as Pivot in Overlapping Preferential Areas

Panel (b) shows the present situation now that the U.K. has joined the EEC. The British have preferential access in two directions, i.e., "one foot in the European ${ }^{1}$ market" and one in the Canadian. ${ }^{2}$

While neither EFTA nor Canada strongly objected to the preferred British position shown in panel (a), there was strong Canadian objection to British entry into the EEC, i.e., the situation shown in panel (b). But even this is instructive: the Canadian objection was not to Britain being a pivot country, with a foot in two different free trade areas, a situation she had enjoyed for many years (in pane1 (a)) without Canadian complaint; rathar the objection was that as a necessary condition of entry, the British had to impose the EEC's common external tariff against Canadian goods. In other words, the Canadian objection was not to the preferred position of the British in two markets, but rather to the loss of the preferred Canadian position in the British market.

T Again note that the recent EEC trade agreements with the important remaining EFTA countries like Sweden have now effectively created one large industrial free trade market, which we refer to as Europe.

2 The line dividing Canada and Britain is shown as a dotted one because British preferences for Canadian goods must end with $U . K$. entry (i.e., the British tariff $t_{B}$ against Canadian imports cannot be preferential, but must be set at the common EEC rate); but Canadian preferences for British goods remain (i.e., the Canadian tariff $t_{C}$ against British goods remains at the previously low preferential rate--although it is not clear how long this special treatment will last). 
In Figure 3, two other examples of overlapping preferential arrangements are shown. Panel (a) illustrates how the EEC now simultaneously has one foot in remaining EFTA markets (1ike Sweden), one foot in Mediterranean markets (1ike Greece and Turkey), and one foot in African markets. No vocal complaint can be discerned from any of its three sets of partners for the asymmetrical preferences this provides to the EEC; for example, Swedish manufacturers do not protest the discrimination they face in Africa or the Mediterranean vis-à-vis EEC manufacturers. ${ }^{1}$ Pane1 (b) shows the Finns with preferential agreements with the Europeans on the one hand and East European countries on the other. In signing a free trade agreement with the Finns, the EEC recognized the necessity of allowing the Finns, because of their special geopolitical situation, to pursue special preferential arrangements with the East Europeans. 2

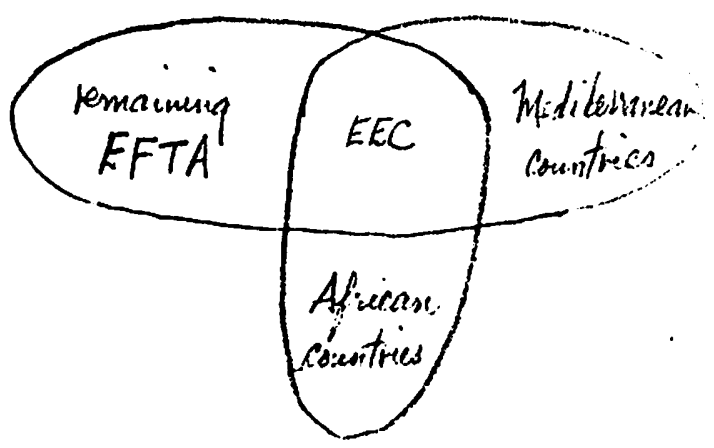

a) EEC as a pivot

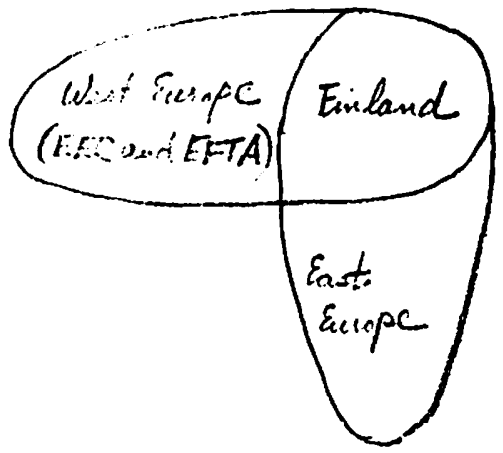

b) Finalnd as a pivot

Figure 3. Other Examples of Overlapping Preferential Arrangements

${ }^{1}$ Protests come, as one would expect, from the Americans who are complete outsiders to these overlapping arrangements; the point is that there is no discernible protest from the EEC's partners.

${ }^{2}$ So far concrete progress has been very limited, with the Finns just beginning to reduce their tariffs vis-a-vis Hungary; (in fact, in dealing with state trading countries, it becomes very difficult even to be sure when you are, or are not, receiving preferential treatment). 
Although this is not a complete cataloguing, these and other available examples point to this conclusion: objections to a country being a pivot for two or more overlapping preferential arrangements are not normally made by its partners, provided their own preferential access to the pivot country's market is not disturbed. ${ }^{1,2}$

\section{The American and European Response}

The first step in approaching the Americans and Europeans would be to sound out their reactions to a full triangular Canada-U.S.-Europe industrial free trade area; in the extremely unlikely chance that this can be negotiated, then it should be. It is only after its (almost certain) rejection that Canada should propose the overlapping free trade arrangement as the remaining way of solving our small-market problem. At this point, the major precedents should be cited. Nonetheless, it would still require a tremendous amount of negotiating energy and imagination. The case could not rest on the argument that Canada is not fully developed, and hence needs protection. Quite the contrary: the argument would be that Canada does not need protection, but rather free access to large markets--a benefit that Europe and the U.S. already enjoy. Otherwise Canadians will face a degree of discrimination that Europe and the U.S. have never, and will never, face; and it is increasing.

In such a diplomatic effort, Canada of course would place more emphasis on the fact that such an arrangement is likely to provide economic benefit to all three parties, than on the fact that Canada would benefit most. But its special beneficiality to Canada follows not from design. Instead it happens to be the economically and politically feasible option left to us because

${ }^{1}$ As Canadian access to the U.K. market was disturbed by British entry into the EEC.

${ }^{2}$ Completely excluded outsiders will object (as the U.S. is objecting to EEC free trade agreements with Sweden, Greece, Turkey, etc.) because the outsider will face discrimination whenever it is excluded from any new free trade area (overlapping or not). 
other avenues are closed. 1

Since the proposal would tend to generate industrial employment in Canada in any case, ${ }^{2}$ we should be prepared to give concrete assurances that we are proposing this to raise real income rather than to generate employment at partners' expense. The first concrete step would be to entertain reform of the Auto Agreement. This would help to establish that our primary objective in trade negotiations is to increase real income rather than employment; (such reform is now very much in the Canadian interest for other reasons as well, since by reducing Canadian auto prices it would add further to the substantial benefits Canada has already realized from this agreement). Second, we should be prepared to provide a guarantee that U.S. and European employment will not be allowed to drift heavily towards Canada, attracted by the preferential advantages provided for the Canadian location. Beyond the obvious guarantee that Canada is a relatively small trading partner with a limited labour force, we should in addition be prepared to agree to keep the Canadian dollar floating, so that any tendency for industrial activity to shift into Canada at partners' expense would be immediately monitored by an appreciation of the Canadian dollar. 3

${ }^{1}$ In this sense it is not in the normal Canadian tradition of making a virtue of necessity; instead it is a necessity that happens to have a great deal of real (rather than contrived) virtue.

2 The creation of any free trade area between partners with escalated tariffs (e.g., Canada and the U.S.) would tend to increase industrial employment in the area as a whole at the expense of excluded countries; the reason is that partners are exchange preferences at third country expense [2]. For reasons that Canada should cxpect to share in that increased employment, see [6]. Pressures of the same sort would apply to canada as pivot in an overlapping free trade arrangement, but they would be of even greater intensity because the pivot country receives more substantial preferences than either of its partners.

3

A floating Canadian dollar also provides a guarantee against our loss of industrial employment for those pessimistic about Canada's ability to compete. For more detail on why this pessimism is well founded if Canadian industry continues to produce using present sma11-market, high-cost techniques, but is not well founded if it specializes for the large markets that would become available, see [6]. 
Moreover, we should be prepared to entertain guidelines on when and how our float may be controlled. All countries are now being forced to address this question in any case; in such circumstances, this could be a useful initiative in an important area of future world monetary reform. ${ }^{1}$ But in any case, allowing the Canadian dollar to appreciate is very much in Canada's interest, because of the possible terms of trade gains it may bring, and because it would buffer the Canadian price level in a period of high world-wide inflation. (It is also difficult to argue that in an overlapping free trade arrangement Canada should hold its dollar down, since this would involve trading the specific economic gains of being a pivot country for the accumulation of foreign exchange reserves--a depreciating asset in a world of serious inflation.) In short, we should view an appreciating dollar in these circumstances not as a failure of exchange rate policy, but rather as a measure of commercial policy success in raising Canadian real income.

There may be some concern in Europe that Canada may become a trojan horse, used by American industry as a location to produce for the European market duty free. The difficulty with this argument is that the Europeans already welcome U.S. investment into Europe itself. It is true that this generates employment in Europe; yet it is a far more direct method for U.S. firms to compete in the common market than U.S. investment in Canada would be. Another possible European fear is that U.S. industry might use Canada as a 'drop off' point for getting products made in the U.S. into Europe duty free. But this fear (and the similar fear Americans might have about European firms using Canada to tranship goods into the U.S.) would be dealt with by appropriately

1 Defining guidelines for controlled floating is a massive problem in itself, involving difficulties that cannot be dealt with in the scope of this paper. There are few clcar analytical guidelines, and no absolutely clean solution is possible; (no matter how limited a country may be in its ability to directly influence its exchange rate, it can always do so by using domestic policies). Nonetheless it is still an important problem, for which (admittedly far from perfect) solutions are being sought. 
specified origin requirements. Curiously, officials seem much more preoccupied with problems of transhipment and origin requirements than with the preferences accorded to the pivot country; (in some cases the latter issue seems not even to be recognized). It is obviously in the Canadian interest not to disturb this preoccupation; accordingly, we should be prepared to accept, if necessary, f rly strict origin requirements, in the interests of achieving the less well recognized (but highly beneficial) advantages of asymetrical preferences in partners' markets.

But perhaps the basic reason why Europe and the U.S. might say yes to this proposal is not just that it would be mutually beneficial, but that the alternative of saying no might be very costly. The reason is that if either partner were to say no, Canada would tend to be directed into a bilateral partnership with the other. ${ }^{1}$ To illustrate, consider the European problem. If they were to reject this proposal, an obvious Canadian alternative would be to seek bilateral free trade with the U.S. ${ }^{2}$ But for the Europeans this would be unattractive politically, since they would be "writing off" Canada-providing no assistance for us in our attempt to resist the centripetal economic pressure of the U.S. Moreover, rejection by the Europeans would be

${ }^{1}$ This is also the reason that, once signed, this agreement would be difficult for either of our partners to abrogate. For more detail on Canada's natural defences against partner abrogating, even in a simple bilateral arrangement, see [8] .

${ }^{2}$ It is essential that Canada impress upon the Europeans that we are very serious about solving our market size problem, the only question being how. Thus our fallback position in the event of a European no would be to seek a free trade association elsewhere (e.g., with the U.S.) rather than doing nothing. (If they believe that our option is to do nothing, then (given their own current 'domestic' problems) it may be impossible even to get their attention on this matter).

Another possible Canadian option in the face of a European no would be the overlapping arrangement of Figure 1, replacing Europe with Japan. Less attractive for Canada than Figure 1 , it still should be more attractive for Canada than a strictly bilateral arrangement with the U.S. The costs of this to Europe would also be greater; accordingly, knowledge that this might be the outcome of the Canadian negotiations would provide even stronger grounds for attracting the Europeans' attention. 
costly economically as well, since it would create a single free trade North American market, complete with discrimination against European goods. 1

If this proposal still could not be sold on any of the above grounds, then there are several additional ways in which it could be made more attractive. ${ }^{2}$ Consider the most important: the guarantee that Canada will not discriminate against any such trading partner in the future sale of resources. Actual contract commitments for future resource supplies might not be necessary; but even if limited commitments of this kind were required, the gains from this proposal would justify them. In fact the real cost of such a commitment might be zero: as Maurice Strong has pointed out, in the last analysis in a world of resource scarcity, Canada cannot sit on all her available resource wealth. Thus committing limited resources in advance may only be bargaining away what we would ultimately have to concede in any case. Moreover, we are already actively considering heavy indirect commitments of future resources: current proposals to open foreign

${ }^{1}$ It is more difficult to predict the U.S. response to the two-sided triangle. While the risk for Europe in saying no would be that Canada might form a bilateral association with the U.S. for economic reasons, the risk for the U.S. would be that Canada might turn to a bilateral association with Europe for political reasons: it would provide better "balance" in our trade, redirecting some of it from the U.S. to Europe. Moreover, in the special circumstances of U.S. rejection, bilateral free trade with Europe might be economically beneficial as well. The reason is that U.S. economic retaliation (the major potential cost of a Canada-Europe arrangement) is less likely: it would be difficult for the U.S. to reject a Canadian proposal for free trade with Europe and the U.S., and then penalize Canada for seeking free trade with Europe. For more details, see [7].

${ }^{2}$ It has been suggested that a concession Canada might make would be to allow the Americans and Europeans to retain their tariffs against a few selected Canadian imports. In other words, by eliminating its industrial tariff across the board Canada would be providing partners (who would be retaining limited tariffs of their own) with more than reciprocity, this compensation offsetting the special advantages of this proposal for Canada. There are two problems with this approach: (1) there might be problems in making it GATTworthy, since it would not involve across-the-board industrial reciprocity; and (2) it would restrict Canada from specializing in the products chosen.

This latter difficulty might be alleviated by selecting some of the products which Canada does not now produce (because of heavy U.S. and European protection), but which we might produce under free trade; this would assuage partners' fears without disturbing present Canadian employment. The potential cost to Canada is that we might be thus blocked out of some of our activities of comparative advantage--but this might not be a heavy price to pay if these considerations are secondary to economies of scale. 
markets for semi-processed resources indirectly implies supplying the resources on which these products are based. And this may expend more resources than our proposal to use a relatively small direct commitment to open all foreign markets-for both semi and fully processed goods. 1 Finally, canadians can expect much more negotiating leverage if we use resources for reciprocal free trade ends than if we use them for a protectionist objective (like generating employment in semiprocessing). It should be emphasized that the point here is not that opening semi-processed markets is necessarily unwise, but rather that resources may be used in a much more important way--to open up our markets across the board. ${ }^{2}$

\section{The Canadian Domestic Response to this Proposal}

The most distressing thought in considering this suggestion is that, despite its asymmetrical advantages for Canada, it might still be more difficult to sell this in Canada than elsewhere. The advantages of free trade over a wide market is a lesson that all other major Western industrial nations have not only. learned, but in addition have already put into practice. On the whole, Canadians are intellectually convinced of the benefits, as witness their almost universal support for the current multilateral round. What we have lacked is a practical vehicle. This would be such a

${ }^{1}$ As an example, suppose we were to sell $\$ 100,000,000$ of semi-processed steel (including $\$ 30,000,000$ of iron or:e). This would use up more resources than the following hypothetical. package: the direct commitment of $\$ 10,000,000$ in iron ore in order to open foreign markets for the sale of both $\$ 50,000,000$ of steel (including $\$ 15,060,000$ of iron ore) and $\$ 40,000,000$ of electrical machinery (including $\$ 2,000,000$ of iron ore).

Moreover, in a resource hutgry world, we would be likely to get more political credit for the direct commitment of $\$ 10$ million of iron ore than any of the other items.

2

2 This argument hinges on rejection of the assumption that under industrial free trade Canadians would concentrate exclusively in producing resources in raw and semi-processed form; for a detailed discussion of this issue, see chapter 14 of [7]. The basic point, however, may be intuitively seen by noting that Pennsylvanians (with some of the richest coal deposits in the U.S. 'free trade area') have not concentrated exclusively in producing coal and steel. 
vehicle. Not only would the long-run benefits to Canada of this proposal

approach (and perhaps even exceed) those of multilateral free trade; in addition, the short-term incidence of adjustment would be far less ${ }^{1}$ because of the special protection we would be receiving in American and European markets.

No other country in history would have ever 1iberalized its trade in one stroke so completely and under conditions so preferentially attractive.

7. The Political Problems: Would they Compare with British Entry into the EEC?

Despite its economic advantages, this proposal would be likely to initially encounter the considerable inertia of Canadian tradition and a fairly cool reception from the Americans and Europeans. ${ }^{2}$ But these problems may be kept in perspective by noting that, in gaining entry into the EEC, the British faced these same difficulties, plus several other important ones in addition. Specifically:

1 This proposal is predicated on a full battery of adjustment assistance programs to cushion the immediate impact effects, as discussed, for example, in [6, Ch. 16]. It is important to note, however, that these costs typically turn out to be substantially less than popularly predicted; moreover, the special preferences for Canada provided by this proposal would tend to reduce these costs even more.

2

2 They can hardly be expected to jump at the opportunity to negotiate this, since the cliici bche Eiciary is Canada. Canadians will have to sell it. But the track record suggests we are pretty good at ti:is. 1 good example was our ability to ncgotiate the Auto Agrcement--which was far more unorthodox and asymmetrically beneficial [1] to Canada than this present proposal. In fact, it may be argued that this is an example of 'overnegotiation' of the Canadian position, since its special provision for protecting Canadian employment has over recent years become counterproductive: the fact that it has not yet been reformed has not only generated considerable hostility in the U.S. (with the result that U.S. decisions in other areas may have been less favourable to Canada, and the American response to any future Canadian initiative may be much cooler); in addition, it has prevented Canada from achieving some further free trade gains (in the form of lower-priced Canadian autos). 
(1) It was not clear that entry into the EEC would be economically beneficial for the U.K., and the British economics profession for good reason was split on the issue. (One of the problems was the degree to which industrial free trade benefits would be offset by the costs of forced participation in the protectionist Common Agricultural Policy, with its adverse income transfers and high food costs.)

(2) At the time of the British decision, the Europeans were engaged in the initial preliminaries designed to lead to European Monetary Union, ' with the objective being to fix exchange rates between the members; this raised the possibility that the U.K. might become an industrially depressed area of Europe--beached on a high cost plateau behind a fixed rate of exchange, and unable to extricate itself by changing the value of the pound. Neither of these problems is inherent in our two-sided proposal, since it involves only industrial free trade, and a continued float of the Canadian dollar. Finally, Canadians who feel that no matter how attractive a proposal may be, it cannot be sold unless it has its own immediate built-in public support should examine the British experience, where public opinion was consistently and strongly opposed to British entry.

\section{Summary}

Canadians are now the recipients of substantial income gains because of the recently improved terms of trade under which we sell our resources. It is important, however, that these gains are not dissipated in subsidizing internationally inefficient industrial activities. A necessary condition for an unsubsidized, internationally efficient industry in Canada is trade liberalization, and in particular the elimination of the tax that faces our products at foreign borders. By opening our major international markets, this proposal is designed to meet that requirement. Thus it provides the

$1_{\text {It }}$ is true that EMU seems to be an increasingly unlikely prospect; but the British decision on entry was made when the odds were more favourable. 
necessary ${ }^{1}$ condition for Canadians to augment their current increases in resource income with increased income based on an internationally competitive level of industrial efficiency. With both, there is no reason why Canadians cannot achieve a potential income at a level probably about as high as for any other country. But without some major new initiative of this kind, there is the substantial risk that Canada will drift even more towards becoming a high-cost industrial cul-de-sac, with increasingly restricted opportunities to sell finished products in the larger more competitive markets that exist elsewhere--and with part of the cost being masked temporarily (but not permanently) by income increases on resource account. Trade liberalization is like technological change: if a country is for some reason frozen out, then the immediate economic cost may be in the order of a few percent of current GNP-no trivial sum; but this is insignificant compared to the 1ong-run cost of being a country in which an internationally competitive industry cannot afford to locate. ${ }^{2}$

$1_{\text {This is }}$ clearly not a sufficient condition; full exploitation of the opportunities of trade liberalization depend on other conditions as well. To cite just one example: Canadians will be required to exhibit a high degree of managerial skill and initiative.

2 The case is strong enough that it should not be overstated. Canada should still remain a good location in industries that are already in, or are very close to free trade: autos, farm implements, resources. (This does not mean that all existing firms in these categories will inevitably remain, for the same reason that the future existence of individual firms in Europe or the U.S. cannot be guaranteed.) The point is, however, that at least Canada would be one of several attractive potential locations, (with perhaps the major disadvantage for such free trade industries being the higher cost inputs that result from protection elsewhere in the Canadian economy).

But in non-free trade industries subject to economies of scale, Canada will not even be on the list of attractive locations: the Canadian market is small, and other markets are costly to service (because of foreign tariffs). Accordingly, in these industries we will tend in the future to be limited to high cost, low volume local Canadian or foreign branch plant operations--as in the past (with remarkably few exceptions). And all Canadians (consumers especially, but producers as well) will continue to pay the cost of not requiring our industry to become internationally competitive. 
The two-sided proposal is a method of keeping Canada from being frozen out--in fact, it is a way of lifting us from last to first in the 1ist of industrial nations successfully pursuing tariff liberalization. The proposal is not as novel as it initially sounds, since Figures 2 and 3 show other examples of pivot countries in overlapping preferential arrangements. There is, of course, no guarantee that Canada would be able to sell this to the U.S. and Europe, but it would be well worth a major effort. It seems quite possible that it can be negotiated more easily than British entry into the EEC; with even very modest supplies of resources in hand, it is unlikely that we would be turned down flat twice. Moreover, there would be no ambiguity (as there was in the British case) about the economic benefits.

The idea is consistent with efforts at multilateral free trade, just as some of the other area initiatives (1ike EFTA) have been. In fact, if it succeeds, it is likely to tend to break down the impasse between the U.S. and Europe, the major stumbling block in the multilateral negotiations. At the very least, simply putting the proposal forward may help to shake up the GATT structure, which is now running heavily towards a U.S./Europe/Japan oligopoly. But the first step is for Canadians to recognize the substantial disadvantages of being an atsider in a world of trade blocs, and that this proposal (or some imaginative variant of it, also consistent with GATT) should be actively pursued. 


\section{References}

1. Beigie, C. E., The Canada-U.S. Automotive Agreement: An Evaluation (Montreal: Canadian-American Committee, 1970).

2. Johnson, H. G., "The Economic Theory of Protectionism, Tariff Bargaining, and the Formation of Customs Unions," Journal of Political Economy, June 1965, pp. 255-283.

3. Lipsey, R. G., "The Theory of Customs Unions: A General Survey," Economic Journal, September 1960, pp. 496-513.

4. Lyon, P., "Canada-U.S. Free Trade and Canadian Independence," Special Study for the Economic Council of Canada (Ottawa: Queen's Printer, forthcoming).

5. Williams, J., "The Canadian-U.S. Tariff and Canadian Industry (McMaster University, unpublished manuscript, 1973).

6. Wonnacott, R. J. and Wonnacott, P., Free Trade Between the United States and Canada: The Potential Economic Efferts (Cambridge, Mass.: Harvard University Press, 1967).

7. Wonnacott, R. J., "Canada's Trade Options," Special Study for the Economic Council of Canada (Ottawa, Queen's Printer, forthcoming).

8. Wonnacott, R. J., "The Political Economy of a Canada-U.S. Free Trade Area: Some Observations," International Journal, Fal1, 1974.

9. Young, J., Canadian Commercial Policy (Ottawa, Royal Commission on Canada's Economic Prospects, Queen's Printer, 1958). 